\title{
MÁTÉ ÁGNES
}

\section{Pacorus és az elképzelt régi magyar irodalom néhány 16. századi francia forrása*}

\begin{abstract}
A jelen tanulmányban Eneas Silvius Piccolomini Historia de duobus amantibus címü novellájának 16. századi francia fordításairól lesz szó. A tanulmány első része könyvészeti jellegü: célja, hogy a néhány éve megjelent French Vernacular Books címü katalógus hibái közül a Piccolomini szerelmi történetére vonatkozóakat helyreigazítsa, és felvilágosítással szolgáljon a számon tartott francia fordítókról és munkáikról. A második rész pedig a szerelmi história állítólagos magyar figurájának, Pacorusnak a francia fordításokban betöltött szerepéról szól: azt vizsgálja, hogyan értelmezik a fordítók Pacorus pannonius nemzetiségét a történetben, és milyen változtatásokat hajtanak végre alakjával kapcsolatban. A szemle végére megtudhatjuk, hogyan avatja hősünket költővé két francia fordító is, akik „megíratják” Pacorusszal a Piccolomini eredeti történetében csak hallomásból ismert Lucretiának szóló két levelet, ezzel gazdagítva a (képzelt) régi magyar irodalom forrásainak csoportját.
\end{abstract}

\section{Bibliográfiai problémák a hat francia forditás körül}

A Historia de duobus amantibus címủ latin novellának a 16. század végéig nyolc nyelven jelentek meg fordításai. Az olasz (4), angol (2), német, spanyol, lengyel, magyar és dán fordítások (1-1) mellett a mü korai francia fordításainak csoportja a legtöbb fordítást számláló szövegegyüttes. A 21. század elejére ugyanis hat francia fordításból maradt fenn legalább egy példány a világ valamely gyüjteményében. A szóban forgó hat fordítás szerzői időrendben a következők: Anthitus la Favre, Octovien de Saint-Gelais, Jean Maugin vagy Millet, François de Belleforest, François de Louvencourt és a csak monogramjáról ismert N. R. „nevü” fordító. Ezeken kívül ismert még Jean Bouchet 16. század végi munkája, amely Anthitus la Favre száz évvel korábbi francia fordításán alapul, így számszerüleg a hetedik ugyan a sorban, de nem tekinthető a Historia önálló francia fordításának. ${ }^{1}$ Bouchet részleges szövege csonka, egyáltalán nem tartalmazza már a Pacorus-epizódot sem, így a magyar kutatás számára értékelhetetlen.

* A tanulmány létrejöttét a Kubinyi András Középkortudományi Alapítvány 2018. évi Kubinyi András-díja támogatta. A szerző az MTA BTK Irodalomtudományi Intézet tudományos segédmunkatársa.

${ }^{1}$ E tanulmány keretei között nem áll módomban részletesen jellemezni a fordításokat, ezért 
1490 körül Lyonban készítette el Maître Anthitus la Favre vagy la Faure a Piccolomini-mủ első francia nyelvű fordítását. ${ }^{2}$ Elise Richter 1914-es monográfiája a fordítás négy kiadását említi. ${ }^{3} \mathrm{~A}$ legfrissebb, ám megbízhatónak egyáltalán nem nevezhető Pettegree-Waslby-Wilkinson-féle bibliográfia, a French Vernacular Books vonatkozó kötete azonban csupán három kiadáshoz kapcsolja Anthitus nevét, ${ }^{4}$ ezen felül tud egy 1515 -ös kiadásról, amely a címleírás alapján szintén Anthitus munkájának utánnyomása volt. ${ }^{5} \mathrm{Az}$ FVB nr. 43817 sorszámon szereplő tétele ${ }^{6}$ azonos lehet azzal, amelyet Elise Richter negyedikként említett kötete bevezetöjében. ${ }^{7}$ A L'ystoire deux vrais amans Eurial et Lucresse címmel, nyomdahely, év és kiadó nélkül megjelent kötet talán ismét csak Anthitus la Favre fordításának egy kiadása lehetett, de mai tudásunk szerint nem maradt fenn belőle példány. A FVB nr. 43813 sorszámú nyomtatványát ${ }^{8}$ pedig az International Short Title Catalogue Anthitus la Favre francia fordításának tartja, és Lyon, Martin Havard, 1494-1495 körüli kiadási időre teszi a typusok fajtája és kopása alapján. ${ }^{9}$ A FVB viszont nem tud egy 1508-as kiadásról, amely már Richter kötetében is szerepelt, az ISTC szintén ismeri, és példány is van belöle Aix-en-Provance Méjanes

sajtó alatt lévő monográfiámhoz irányítom az olvasót. MÁTÉ Ágnes, Egy kora újkori sikerkönyv története, XV-XVI. századi szövegvariánsok és forditások Eneas Silvius Piccolomini Historia de duobus amantibus címü szerelmes regényéböl, Bp., Reciti, 2018, megjelenés alatt.

${ }^{2}$ La FAURe, Anthitus, Lystoire des deux vrays amans eurial \&la belle lucresse, Lyon, Jean de Vingle, 1490 körül.

3 Eurialus und Lukrezia l'ystoire de Eurialus et Lucresse, vrays amoureux, selon pape Pie, übers. von Octovien de Saint-Gelais, mit Einl., Anm. u. Glossar hrsg. von, Halle a. s., Niemeyer, 1914, X.

${ }^{4}$ French Vernacular Books, Books Published in the French Language before 1601, French Vernacular Books $H-Z$, ed by Andrew Pettegree, Malcolm Waslby, Alexander Wilkinson, Leiden, Brill, 2007, 569., (a továbbiakban: FVB). A FVB leírásait szó szerint idézem, a lelőhely információkat pedig saját ellenőrzésem alapján teszem hozzá. nr. 43796 Pius II. Faure, Anthitus (tr.), De duobus amantibus Euryalo et Lucretia, [Lyon], s. n., [1490], 8o. http://istc.bl.uk/search/search. html?operation=record\&rsid=445384\&q=98 nr. 43798, Pius II. Faure, Anthitus (tr.), De duobus amantibus Euryalo et Lucretia, [Lyon, Jean de Vingle, 1494]. 4o. Lelöhely: Paris, Bibliothéque Nationale de France http://istc.bl.uk/search/search.html?operation=record\&rsid=445384\&q=101 nr. 43804, Pius II. Anthitus (tr.), L'ystoire deulx[!] vrays amans Eurial et la belle Lucresse. Lyon vend Olivier Arnoullet, [1528], 4o. Lelőhely: Grenoble, Bibliothéque municipales, F.7293 Rés.

${ }_{5}$ FVB, nr. 43801, Pius II. L'ystoire deux vrais amans Eurial et la belle Lucresse. Lyon, Jean de Vingle, 1515. 16o. Lelőhely: Aix-en-Provance, Bibliothéque Méjanes, Rés. S. 024,10.

${ }^{6}$ FVB, nr. 43817 Pius II. L'ystoire deux vrais amans Eurial et Lucresse. S. 1., s. n., s. d., 4o. Brunet I 69. Brunet, Jacques-Charles, Manuel du librarie et de l'amateur de livres, vol. I., Paris, Firmon-Didot, 1860, nr. 69.

7 Richter 1914, i. m. X. Így: 4. Lystoire de deux vrays amans eurial et lucresse etc., s. 1. n. d. in-4o goth., Heft A enthält nur sechs Blätter.

${ }^{8}$ FVB, nr. 43813 Pius II. L'ystoire deux vrais amans Eurial et la belle Lucresse. [Lyon, Martin Havard], s. d., 4o. Lelöhely: Bibliothéque de l'École Nationale Supérieure des Beux Arts.

${ }^{9} \mathrm{http}: / /$ istc.bl.uk/search/search.html?operation=record\&rsid=445384\&q=100 ISTC ip00686350. 
gyüjteményében, valamint a müncheni Bayerische Staatsbibliothekban. ${ }^{10}$ Anthitus munkáját én a Münchenben őrzött, 1508-as kiadásban vizsgáltam meg, ${ }^{11}$ és közvetlen textológiai összehasonlításom is azt igazolja, hogy a FVB által ismert, egyik 1537-es kiadvány, amelyből ma Chantilly-ben a Musée Condé gyüjteményében is van példány, ${ }^{12}$ szintén Anthitus fordításának egy másik kiadása. William Kemp koncentrált könyvészeti vizsgálatai szintén azt mutatták, hogy a chantilly-i példány is Anthitus munkája. Kemp Anthitus fordításának összesen nyolc, 1540 előtt megjelentetett kiadását számolta össze, s a kérdésben jelenleg az ő adatait kell mérvadónak tekinteni. ${ }^{13}$

Körülbelül Anthitus la Favre fordításával egy időben dolgozott saját változatán Octovien de Saint-Gelais, aki munkáját 1493-ban Párizsban jelentette meg, ${ }^{14}$ és fordításának egyben ez az egyetlen ismert kiadása is. ${ }^{15}$ Saint-Gelais 4700 sornyi versben fordította le a két szerelmes történetét, elsősorban metrikai megfontolások miatt jelentősen bővítve az elbeszélést. Saint-Gelais kiadásának fontos jellemzője, hogy a történet egyes szakaszainak alcímeket ad, ún. rubrikákkal, egy-két soros összefoglalókkal látja el őket, hogy ezzel is segítse olvasóit a történetben való tájékozódásban.

Időrendben egy 1537-es, ismeretlen fordító tollából származó francia változat következik. A FVB két külön tételszám alatt vesz fel két, ebből az évből szárma-

${ }^{10}$ Pius II, Pont. Max. (formerly Aeneas Sylvius Piccolomini), De duobus amantibus Euryalo et Lucretia [French] (Tr: Anthitus Faure), Paris: Michel Le Noir, [about 1508], 4 ${ }^{\circ}$ ISTC No.: ip00686420. Lelőhely: Aix-en-Provance, Bibliothéque Méjanes, Inc. D. 14-15,2. http://istc.bl.uk/ search/search.html?operation=record\&rsid $=445384 \& q=102$

${ }^{11}$ Az általam vizsgált példány: Faure, Antithus, Histoire des deux vrays amans Eurial et la belle Lucresse, Paris, [kb. 1508], München, Bayerische Staatsbibliothek 4 Inc. s. a. 1733 h. http:// daten.digitale-sammlungen.de/ db/0010/bsb00107025/images/index.html?id=00107025\&groesser $=\&$ fip $=$ eayaxsfsdrfsdrewqxdsydsdaseayafsdrsdas \&no $=18 \&$ seite $=7$

${ }^{12}$ FVB, nr. 43807 Pius II. L'historie delectable et recreative de deux parfaitcz[!] amans, estans en la cite de Sene. [Paris, Denis Janot], 1537. 16o. Lelöhely: Chantilly, Musée Condé, XI-D-029.

${ }^{13}$ Kemp, William, Des deux amans de Piccolomini. Les éditions de la traduction lyonnaise antérieures à 1540 (J. de Vingle, M. Havard, M. Le Noir, O. Arnoullet et D. de Harsy) = Réforme, Humanisme, Renaissance, Anneé 2011, Volume 71, 23-33. http://www.persee.fr/doc/rhren_1771-1347_2011_num_71_1_3113

${ }_{14}$ L'ystoire de Eurialus et Lucresse. Vrays amoureux. Selon Pape Pie, Párizs, Antoine Vérard, 1493.

15 FVB, nr. 43797 Pius II. Saint-Gelais, Octovien (tr.), De duobus amantibus Euryalo et Lucretia [Paris, Antoine Vérard, 1493]. 2o. Lelőhely: Paris, Bibliothéque Nationale de France; Paris, Bibliothéque de l'Arsenal; Bibliothéque Mazarine; London, British Library; Oxford, Bodleian Library. http://istc.bl.uk/search/search.html?operation=record\&rsid=445384\&q=99

Legutóbbi modern kiadása: E. S. Piccolomini, Oeuvres érotiques. Cinthia - Historia de duobus amantibus avec Lystoire de Eurialus et Lucresse dOctovien de Saint-Gelais - De remedio amoris, Présentation et traduction par Frédéric Duval, Turnhout, Brepols, 2003. A következő kötet csak Saint-Gelais és la Favre munkáiról ad hírt: Translations médiévales. Cinq siècles de traduction en français au Moyen Âge $\left(X I^{e}-X V^{e}\right)$ Étude Répertoire, Volume 2 La Corpus Transmedié: Répertoire, „enfer”, ,purgatoire”, et ,, limbes”, sous la direction de Claudio Galderisi, avec la collaboration de Vladimir Agrigoroaei, Brepols, 2011, 250-254. 
zó kiadást. Az egyik név és hely nélkül megjelent múvet már Brunet 19. századi bibliográfiája ismerte, ${ }^{16}$ viszont mai tudásunk szerint nem maradt fenn belöle példány. Ennek következtében nem lehetséges megállapítani, hogy azonos-e a fent már említett, másik 1537-es kiadvánnyal, amelyből a Musée Condé gyüjteményében is van példány, és amely Anthitus la Favre munkájának egy kiadása. ${ }^{17}$

A következő csomópontot az 1551-ben I. M. fordítói monogrammal megjelent francia fordítás jelenti, amely szintén kihívás elé állítja a filológusokat, mivel egymásnak ellentmondó adatokat találhatunk róla. Egyrészt a FVB a 16. századi Du Verdier magángyüjtemény katalógusa alapján veszi fel tételként a fordítást, amelynek szerzője e szerint egy Jean Millet nevü személy volt, ${ }^{18}$ viszont a fordításnak fennmaradt példányáról nem tud. Másrészt pedig a FVB egy I. M. monogramú fordító 1554-ben megjelent, eltérő címü kiadásáról is tud, amelyből a müncheni Bayerische Staatsbibliothekban öriznek - állítása szerint - egy példányt. ${ }^{19}$ Egy szakíró, Sergio Cappello cikkében ${ }^{20}$ azonban nemcsak monogramosan említi a müncheni példány szerzöjét, hanem kijelenti róla azt is, hogy az Jean Millet-vel azonos, és véleménye szerint a példány címlapján álló évszám nem 1554-nek, hanem 1551-nek olvasandó, jóllehet a Bayerische Staatsbibliothek katalógusába is 1554 -es évszámmal van felvéve. ${ }^{21}$ Tovább bonyolítja a helyzetet, hogy Frédéric Duval 2003-ban megjelent, Saint-Gelais több fordítását tartalmazó kiadásában az egyéb francia fordítások között egész más címmel hivatkozik Jean Millet fordítására, ${ }^{22}$ de ő is 1551 -es kiadási dátumról tud - valószínüleg szintén Du Verdier alapján, bár Duval nem ad meg hivatkozást az adathoz. Tény azonban, hogy ma példányt csak abból a kiadásból ismerünk, amelyet Münchenben őriznek, és amelyen a fordító neve csupán kezdőbetükkel szerepel, a kiadási évszám utolsó számjegye pedig jótékonyan egy nyomdadísz alá van rejtve. A fordítás előtt álló dedikáció azonban 1550. november 27-röl datálódik, s ha ez a kiadás ennek

${ }^{16}$ FVB, nr. 43806 Pius II. L'historie delectable et recreative de deux parfaits amans. S. 1., s. n., 1537. 16o. Brunet I 69.

${ }^{17}$ FVB, nr. 43807 Pius II. L'historie delectable et recreative de deux parfaitcz[!] amans, estans en la cite de Sene. [Paris, Denis Janot], 1537, 16o. Lelőhely: Chantilly, Musée Condé, XI-D-029.

${ }_{18}$ FVB, nr. 43808 Pius II. Millet, Jean (tr.), L'historie des amours d'Eurialus et Lucrece. Paris, Nicolas Chrestien, 1551. 80. Du Verdier, 726. Du Verdier, Antoine, La bibliothéque d'Antoine Du Verdier, contenant le catalogue de tous ceux qui ont escrit, ou traduit en françois, Lyon, 1585. Szintén Du Verdier alapján hozza az adatot: Gustav REYNIER, Le roman sentimental avant l'Astreé, Genéve, Slatkine Reprints, 1969 [eredeti megjelenés: 1908], 29.

${ }^{19}$ FVB, nr. 43809 Pius II. M., I. (tr.), Histoire touchant les amours d'Eurialus et Lucrece, Paris, Antoine Le Clerc, 1554. 8o. Lelöhely: München, Bayerische Staatsbibliothek, P. lat. 1851 g.

${ }^{20}$ Cappello, Sergio, $L$ 'édition des romans médiévaux á Lyon dans la premiére moitié du $\mathrm{XVI}^{e}$ siécle = Réforme, Humanisme, Renaissance, Anneé 2011, Volume 71, Numéro 1, 58, j. 82.

${ }^{21} \mathrm{http} / / /$ reader.digitale-sammlungen.de/de/fs1/object/display/bsb10189007_00005.html

22 Így: Jean MiLLET, L'istoire delectable et recreative de deux parfaits amants estans en la cité de Sene ..., Paris, Nicolas Chrestien, 1551. Piccolomini 2003, i. m. 31, j. 42. 
a fordításnak az első megjelenése volt, mint feltételezhető, akkor ez az 1551-es kiadási dátum mellett szóló érvként esik latba. ${ }^{23}$

Frédéric Duval ${ }^{24}$ utalt egyik lábjegyzetében egy Jean Maugin nevéhez füződő francia fordításra is, amely 1556-ban jelent meg. Szerencsére a budapesti Országos Széchényi Könyvtár munkatársai kérésemre kiderítették, hogy Jean Maugin fordítói neve alatt (a köteten azonban csak a fordító I. M. monogramját feltüntetve) őriznek egy ritka példányt az oxfordi Lady Margaret Hall gyüjteményében, így a művet digitális másolatban meg tudtam vizsgálni. ${ }^{25} \mathrm{Ez}$ a vizsgálat azonban arra az eredményre vezetett, hogy a müncheni 1551/1554-es - digitalizálva bárki számára hozzáférhető -, Jean Millet neve alatt számon tartott fordítás teljesen azonos azzal, amelyből az oxfordi Lady Margaret Hallban egy 1556-os kiadást őriznek, Jean Maugin fordítói neve alatt. Nem áll módomban eldönteni, hogy Jean Millet vagy Jean Maugin volt-e valójában a fordító, mivel nincs tudomásom más müvükről, amellyel össze lehetne hasonlítani őket, s ez egyébként is a régi francia nyelvben nálam jártasabb kutató feladata lenne. Ezért önkényesen a Lady Margaret Hall azonosítása mellett döntöttem, tehát ezt a fordítást az alábbiakban Jean Maugin neve alatt fogom tárgyalni.

A következő francia fordítás Piccolomini Historiájából olasz eredetü történeteket, főként Matteo Bandello elbeszéléseit tartalmazó, többkötetes sorozatba került be, amelyet egy François de Belleforest nevü fordító-szerkesztő állított össze. ${ }^{26}$ Ezt a fordítást szintén nem említi a FVB bibliográfia.

A FVB bibliográfia utal azonban egy 1598-as, Jean Gesselin nyomdájában megjelent kiadásra, amelyből állítása szerint Münchenben is van példány. ${ }^{27}$ Ezt a fordítást egy N. R. monogramú személy jegyzi, Bourgogne tartomány kormányzójának, de Rion marsallnak dedikálva a munkát. Az FVB bibliográfia külön tételként vesz fel egy szerinte másik, szintén 1598-as megjelenésű fordítást, amelyből állítása szerint szintén Münchenben, valamint Prágában maradt fenn példány. ${ }^{28} \mathrm{~A}$ müncheni katalógus csupán az imént említett, Jean Gesselin által kiadott, 1598-as kötetre ad találatot, ráadásul az Universal Short Title Catalogue

${ }^{23} \mathrm{http} / / /$ reader.digitale-sammlungen.de/de/fs1/object/display/bsb10189007_00006.htm1 ?zoom $=0.55$

${ }^{24}$ Így: Jean Maugin, L'amour d'Eurialus et Lucresse, par lequel est succintement demonstré quel profit vient du chaste amour et quel dommage de l'impudique. Avec quelque epistres..., Lyon, 1556. Piccolomini 2003, i. m. 31, j. 42.

${ }^{25}$ Maugin, Jean, L'amour d'Eurialus et Lucresse, par lequel est succintement demonstré quel profit vient du chaste amour et quel dommage de l'impudique. Avec quelque epistres..., par Benoist Rigaud \& Jan Saugrain, Lyon, 1556. Lady Margaret Hall Library, Briggs Room: 847.28 2(1).

${ }^{26}$ De Belleforest, François, Histories tragiques extraites de l'italien de Bandel..., Vol. 6., Paris, Jean Bordeaux, 1582, ff. 230-267.

${ }^{27}$ FVB, nr. 43814, Pius II. Les amours d'Eurial et de Lucresse. Paris, chez Jean Gesselin, 1598, 12o. Lelöhely: München, Bayerische Staatsbibliothek, P.o. gall. 671. http://reader.digitale-sammlungen.de/de/fs1/object/display/bsb10189272_00001.html

${ }^{28}$ FVB, nr. 43815, Pius II. Les amours d'Eurial et de Lucresse. Paris, s. n., 1598. Lelöhely: München, Bayerische Staatsbibliothek. Prága, Strahovská knihovna. 
információja szerint a müncheni P.o. Gall. 671 jelzetü kötet, vagyis az egyetlen Münchenben őrzött 1598-as francia fordítás, és a prágai AE XI 101 jelzetü kötet ${ }^{29}$ azonos kiadást takarnak: Pius II, Les amours d'Eurial et de Lucresse, Paris, s. n., $1598 .{ }^{30}$ A megadott internetes hivatkozás az USTC oldaláról a BSB digitális könyvtárába vezet tovább, ahhoz a kötethez, amelynek címlapján világosan olvasható, hogy Jean Gesselin adta ki, tehát semmiképpen sem lehet sine nomine a nyomdász a könyvészeti leírásában! Bohemista kutatók segítségével ${ }^{31}$ sikerült kiderítenem, hogy a prágai és a müncheni példányok valóban azonosak egymással: tehát a Pettegree-Waslby-Wilkinson-féle bibliográfia nr. 43814 és nr. 43815 tételei ugyanannak a kiadásnak, a Jean Gesselinnél kiadott, 1598-as francia Piccolomini-fordításnak a példányai, és a FVB-ban található bibliográfiai leírásuk hibás, mert a nyomdász igenis fel van tüntetve a kiadáson, Jean Gesselin az. ${ }^{32}$

Az alábbi kiadást szintén nem tartalmazza a FVB bibliográfia, jóllehet annak létezését már Gustav Reynier 1908-ban megjelent munkája említette, ${ }^{33}$ és Frédéric Duval is utalt rá 2003-as kötetében: ${ }^{34}$ François de Louvencourt, Les Amans de Sienne, où l'on prouve que les Femmes font mieux l'amour que les Vefves et les Filles, Paris, 1598, Jean Gesselin, 4o. A Bibliothéque National de France gyüjteményében jelzete 8-BL-17913. A könyv állapota miatt - állományvédelmi okokra hivatkozva - a könyvtár a másolást 2016 májusában megtagadta, és az online kikérő rendszer alapján a helyben olvasását sem teszik lehetővé, így a kötetet nem volt alkalmam megvizsgálni. Michel Bideaux egy, a korai francia Historia-fordításokról szóló cikke végén szentelt pár sort e fordítás jellemzésének, ${ }^{35}$ de a Pacorus-epizódról nem ejtett szót benne, így jelen cikk szempontjából Louvencourt fordítása értékelhetetlen.

Végezetül szintén Gustav Reynier kötetéből ${ }^{36}$ tudunk egy kiadásról, amely szerint Octovien de Saint-Gelais száz évvel korábbi fordítását dolgozza át egy Jean Bouchet nevü szerző: Jean Bouchet, Les Angoisses et remedes d'amours du traverseur á son adolescence. Auquel est adjousté une plaisante histoire d'Eurial et Lucresse redigee en langue latine par Aenas Sylenius(sic) poete(sic) excellent

${ }^{29} \mathrm{http} / / /$ knihovna.strahovskyklaster.cz/l.dll?cll P=132571 (Letöltés: 2016. 06. 23.)

${ }^{30} \mathrm{http} / / /$ ustc.ac.uk/index.php/record/39139 (Letöltés: 2016. 06. 23.)

${ }^{31}$ Itt is szeretném megköszönni Berkes Tamás, Pató Márta és főként Miloš Sládek segítségét, aki a prágai példányt összevetette a müncheni digitális példánnyal.

${ }^{32}$ N. R., Les amours d'Eurial et de Lucresse. Paris, chez Jean Gesselin, 1598. A müncheni példányt idézem.

33 ReYNiER 1969, i. m. 29. Reynier a münek egy 1706-ban Leidenben kiadott, szintén 12o alakú kiadását is említi.

${ }^{34}$ Piccolomini 2003, i. m. 31.

35 Bideaux, Michel, L'Historia de duobus amantibus nel Cinquecento francese = Pio II e la cultura del suo tempo: Atti del I convegno internazionale, a c. di Luisa Rotondi Secchi Tarugi, Guerini, 1991,175-188, föként 186.

36 ReYNIER 1969, i. m. 29. Reynier a münek egy 1602-ben ugyanott kiadott, szintén 12o alakú kiadását is említi. 
et depuis trad. en vulg. fr. Rouen, Ab. Cousturier, 1599, 12o. A kötet a Bibliothéque National de France gyüjteményében a RES P-YE-2552 jelzeten elérhető.

Közvetlen szövegvizsgálatom azonban megállapította, hogy Reynier adatai némi korrekcióra szorulnak: a fordítás szerzőjének neve az 1599-es kiadási idejü példányon nem Bouchet, hanem Bouchier alakban szerepel, ${ }^{37}$ a fordítás pedig az első francia fordító, vagyis Anthitus la Favre munkájának egy részét veszi át a Historia de duobus amantibus fordításaként, nem pedig Saint-Gelais fordítását másolja. Reynier-t az vezethette félre, hogy Bouchet ajánlásában valóban említi Octovien de Saint-Gelaist, mint olyan szerzőt, aki leoninusokban fordította franciára Ovidius leveleit és Vergilius Aeneisét. ${ }^{38}$ Elegendő azonban összevetni egymással Saint-Gelais fordításának, és a Bouchet neve alatt megjelent Historia-fordításnak a kezdősorait, hogy lássuk, a két szöveg teljesen eltér egymástól: ${ }^{39}$

Saint-Gelais: „En l'onneur de la saincte Trinité, / Louange de vous, Charles, roy treschrestien, / De latin en francois j'ay translaté [..." ${ }^{\prime 40}$

Bouchet: „A La requeste et priere des Dames / Ausquelles sont les bons obeyssans / Sans vouloir choses qui soyent infames" $[\ldots]^{41}$

Teljesen világos azonban az egyezés Bouchet fent idézett incipitje és Anthitus kezdősorai között:

Anthitus la Favre: „A La requeste et priere des Dames / Ausquelles sont les bons obeyssans / Sans vouloir choses qui soyent infames" $[\ldots]^{42}$

A Bouchet neve alatt megjelent Les Angoisses et remedes d'amours ... (A szerelem kínjai és orvosságai ...) címü nyomtatvány $72 \mathrm{v}-86 \mathrm{r}$ oldalain olvasható tehát Anthitus Historia-fordításának rövidített változata, amely Lucresse és a Raison párbeszéde után az Auctuer megszólalásával ér véget.

${ }^{37}$ Bouchet, Jean, Les Angoisses et remedes d'amours du traverseur á son adolescence. Auquel est adjousté une plaisante histoire d'Eurial et Lucresse redigee en langue latine par Aenas Sylenius(sic) poete(sic) excellent et depuis trad. en vulg. fr., Rouen, Ab. Cousturier, 1599, Bibliothéque National de France, RES P-YE-2552, 2r oldalán így szerepel a név: Iean Bouchier de Poitiers.

38 Bouchet 1599, i. m. 3r: „Et en rithme platte (qu'on appelle Leonine) n'ordonnois n'entrelassois les masculins et feminins vers, comme a communement faict Monsieur Octavian de Sainct Gelaiz, Evesque d'Angoulesme, es ses epistres d'Ovide, et Aeneide de Virgile par luy de Latin en Françoys traduicte."

39 Reynier könyvének írása idején (1908 elött) még csak az eredeti incunabulum és antikva kiadások álltak rendelkezésre mind Saint-Gelais, mind Anthitus la Favre munkáiból, de ez nem menti fel Reyniert az alól, hogy nem ellenörzött tényt, csupán feltételezést közölt tanulmányában.

40 Piccolomini 2003, i. m. 87. „A Szentháromság tiszteletére / Az ön magasztalására, Károly, legkeresztényibb király / latinról franciára fordítottam [...]”.

${ }^{41}$ Bouchet 1599, i. m. 72r. „A Hölgyek kérésére és imájára / Akiknek engedelmeskedni jó / S az akaratukkal ellenkező rossz hírüvé lesz [...]”.

${ }^{42}$ FAURe 1508, i. m. Aii. 
Anthitus teljes fordítása még kb. nyolcvan oldalt számlál, de Bouchet kötetében a történetnek itt vége szakad, és a 86v-87r oldalakon Piccolomini egy másik munkájának, az epistola revocatoriának egy rövidített, verses átdolgozását olvashatjuk franciául szintén Bouchet tollából. Vannak rá jelek, hogy Bouchet olvasta Piccolomini müveit latinul is, s talán kötete első részéhez, a címadó „Szerelem kínjai és orvosságai" verses fejezetekhez is töle vette az ihletést, ${ }^{43}$ de a Historia de duobus amantibus szövegét nem fordította le, csupán újrahasznosította egy száz év előtti francia fordító munkáját. ${ }^{44}$

Bouchet szerzői nevével kapcsolatban pedig megjegyzendő, hogy a Biographie Universelle szerint ${ }^{45}$ létezett egy 1476-ban Poitiers-ben született Jean Bouchet, akinek elöször 1536-ban, majd 1537-ben és 1550-ben jelent meg különbözö formátumokban a Les Angoisses et Remedés d'amour du traverseur en son adolescence címü munkája. Véleményem szerint a Reynier által említett 1599-es kiadás ugyanennek a poitiers-i Bouchet-szövegnek az újabb kiadása. Annak a magyarázata, hogy az 1599-es kiadás címlapján miért Bouchier névalak áll, a következő lehet. A 16. század végén élt egy akkor jóval híresebb, a Szent Liga érdekében propagandát folytató teológus szerző, Jean Boucher, ${ }^{46}$ több Párizsban megjelent munka sajtó alá rendezője, s talán az ő neve vezette félre a roueni nyomdászt, aki egy hatvan évvel korábban megjelent munkát adott ki újra.

\section{Pacorus, az elképzelt magyar irodalom költöje}

Piccolomini eredeti történetében a Zsigmond császár kíséretébe tartozó magyar lovag, Pacorus is beleszeret Lucretiába, és mivel bízik saját fizikai vonzerejében, úgy dönt, hogy megkísérti az asszonyt. ${ }^{47}$ Elöször egy szerelmes verset (carmen amatorium) ír neki, amelyet egy virágcsokor szárába rejtve ad át, mikor az asszony

${ }^{43}$ Bideaux híradása szerint Piccolomini De remedio amoris című müvét Albin des Avenelles francia fordításában már kétszer kiadták az 1540-es években, és létezik egy 15. század végi kéziratos francia fordítása is. A későbbi kutatás feladata lesz, hogy Bouchet/Bouchier munkáját ezekkel összevesse. BideAux 1991, i. m. 184, j. 27.

${ }^{44}$ Egy francia kutató, Daniel Maira kedvezőbben fogalmaz: „L'Hisotire des deux amants est ainsi réduite à l'essentielle [...]" lásd: MAIRA, Daniel, Une édition des Angoisses et remédes d'amour de Jean Bouchet suivi de l'Histoire d'Eurialus et Lucresse d'Enea Silvio Piccolomini = Revue des Littératures de l'Union Européenne, 2/2007, n. 7, 233-258, itt: 243.

${ }^{45}$ Biographie Universelle (Michaud) Ancienne et Moderne, Tome Cinquième Bo-Br, Paris, Leipzig, 1812, 174. Az ott felsorolt kiadások: Poitiers, de Marnef, 1536, in-4o, goth.; Ibidem, 1537, in-12o; Lyon, de Tournes, 1550, in 160.

46 Lestringant, Frank, Rieu, Josiane, TARrÊTE, Alexandre, Littérature française du XVIe siècle, Paris, Presses Universitaires de France, 2000, 334.

${ }^{47}$ Piccolomini, Enea Silvio, Historia de duobus amantibus, a c. di Donato Pirovano, Edizioni dell'Orso, 2001, 78. „Pacorus interea, Pannonius eques, domo nobilis, qui Ceasarem sequebatur, ardere Lucretiam cepit. Et quia formosus erat, redamari putabat solamque femine pudicitiam obstare sibi rebatur." 
szolgálóival a Sienához közeli Santa Maria di Betlehem-kápolnába tart. Lucretia ugyan elveszi a csokrot a lovagtól, de rögtön át is adja egyik szolgálójának, akitől néhány diák elkéri, és felfedik a levél titkát. A latin novella tanúsága szerint tehát a vers első olvasói a diákok, azután Menelaus, Lucretia férje, végül maga a császár, akihez a dühös férj elrohan feljelentést tenni. A kitört botrány hatására Pacorus megfogadja, hogy többé nem zaklatja Lucretiát. A narrátor mindezekről az eseményekről függő beszédben számol be, így a szerelmes vers tartalmát tôle nem ismerjük meg, bár nyilván nem okozott volna nehézséget Piccolomininek, hogy a novella többi sorához hasonlóan, ügyes intertextuális játékkal Pacorus nevében megkomponáljon például egy Ovidius-centót.

Lucretia második megkísértésére a téli havazás szolgáltat alkalmat Pacorusnak: az ifjak hógolyókat hajigálnak az asszonyok ablakába, akik viszonozzák a tréfát. Pacorus második levelét viaszba rejtve egy hólabdába gyúrja, és feldobja Lucretia ablakába. A hólabda azonban a tüz mellett landol, ahol elolvad, és a tüznél melegedő vénasszonyok találják meg Lucretia helyett a szerelmes levelet. Menelaus ismét a császárhoz siet, és Pacorus a büntetést elkerülendő elszökik a városból. A történtekről ezúttal is csak narrátori tájékoztatást kap az olvasó.

Mivel Piccolomini novelláját megjelenése óta igaz történetként olvasták, több kísérlet is történt a szereplők valós sienai személyekkel való azonosítására. ${ }^{48}$ Ezek közül a legtalányosabb éppen Pacorus alakja, akinek még a novellabeli névadását sem értjük teljesen. Pacorus Orodes pártus király fia volt, aki a C. Ventidius Bassus római vezér elleni harcban esett el Kr. e. 38-ban, nagy bánatot okozva ezzel idős atyjának. Nem igazán világos, hogy melyik, Zsigmond császár kíséretében lévő magyar foúrra illene ez az allúzió. Ha jól értem, E. Kovács Péter könyvében felveti, hogy a magyar lovag Hunyadi Jánossal lehetett azonos, hiszen az az ismert pletyka-propaganda arról, hogy Zsigmond volt a Törökverő apja, párhuzamként szolgálhatna Orodes és Pacorus viszonyára. E. Kovács azonban azon az alapon el is veti ötletét, hogy Hunyadi bizton megszerezte volna a Lucretia neve alatt rejtező nőt, ő nem vallott volna kudarcot a hódításban. ${ }^{49}$ E. Kovács könyve ugyanakkor tartalmaz érdekes adatokat, amelyeken elindulva, levéltári kutatásokkal talán nem lehetetlen többet megtudni a keresett magyar lovagról. ${ }^{50}$

Mindenesetre Piccolomini fikciója szerint a magyar irodalomtörténet gazdagodik egy álnéven (és valószínúleg olaszul) ${ }^{51}$ író alkotóval, akinek a szövege azonban fizikailag nem születik meg egészen addig, amíg a latin Piccolomini-novella francia fordítókra nem talál. A fordítások többszörös áttételessége miatt ez

${ }^{48}$ Frugoni, Arsenio, Enea Silvio Piccolomini e l'avventura senese di Gaspare Schlick = Rinascita, 1941, 4, 229-249.

49 E. Kovács Péter, Zsigmond király Sienában, Bp., Corvina, 2014, 164.

${ }^{50}$ Különösen E. KovÁcs 2014, i. m. 50.

${ }^{51}$ Hiszen Piccolomini fikciója szerint Eurialusnak meg kell tanulnia toszkánul, hogy hölgyének egyedül, titokban is tudjon írni, és ezeket a leveleket azután Piccolomini latinul tárja olvasói elé. Piccolomini 2001, i. m. 46. 
még a Páduai ének $k^{52}$ történeténél is bonyolultabb helyzet, ${ }^{53}$ ezért részben Szigeti Csaba felvetéséből kiindulva én e szövegeket nem a lehetséges, hanem inkább az elképzelt magyar irodalom darabjainak nevezem. ${ }^{54}$ Úgy vélem, Szigeti besorolásában az Eco Baudolinójától írt János pap leveleihez hasonlítanak leginkább: egy szerző tollán született, vagy a kollektív fantáziában létező irodalmi alak virtuális szövegét más szerzők aktuális szöveggé teszik.

A Historia de duobus amantibus hat korai francia fordítása közül egyet, François de Louvencourt alkotását nem tudtam kézbe venni, így sajnos nem tudok beszámolni Pacorus abban játszott szerepéról sem. Egy másik fordító, François de Belleforest jelentősen megkurtított Historia-verziójából pedig teljesen kimarad a magyar lovag hiábavaló próbálkozása Lucretia meghódításáért. Octovien de Saint-Gelais és Jean Maugin eléggé hüséges fordításaiban azonban a magyar lovag epizódja is helyet kap. Saint-Gelais verses változatában így kezdődik a férfi bemutatása:

Ce temps pendant un homs panonïen,

Homme noble, Pacorus eut en nom $[\ldots]^{55}$

Ezután megtudunk mindent róla, amit Piccolomini latin eredetijéből már tudunk: hogyan szeret bele Pacorus Lucretiába és hogyan kísérti meg két írásával is az asszonyt, hogy a dolog kiderülvén végül szégyenszemre el kelljen hagynia Siena városát.

Jean Maugin 1551/1554 és 1556-os kiadású munkájának fontos jegye, hogy müvészien ugyan, de nagyon szorosan követi latin forrását, így Maguintől sem tudunk meg sem többet, sem kevesebbet a lovagról, mint amit már Piccolomini megosztott róla olvasóival. Maugin francia szövegében így kezdődik a Pacorus-epizód: „Ce pendant Pacorus de Pannonie chevalier de lordre, homme de noble lignee, estant en la compagnie de L'empereur s'enamoura de Lucresse [...]." ${ }^{.56}$

A két, témánk szempontjából legérdekesebb francia fordítás következik most, amelyekben Pacorus saját szavait is olvashatjuk. Az egyik, Anthitus la Favre munkája, a francia fordítások között időrendben is az első, amelyet 1490 körül vetett papírra szerzője. ${ }^{57}$ Anthitus munkájának kiadásaiban a férfi neve következetesen a -rus szótag helyett -urs szótaggal végződik, Pacours formában. A rá vonatkozó rész így kezdődik ebben a fordításban: „chevalier [...] de noble masion du pays

52 Kőszeghy Péter, Balassi Bálint, Magyar Amphión, Bp., Balassi, 2014, 112-117.

${ }^{53}$ Hiszen ott a magyar éneket latinra, azt pedig olaszra fordították, itt pedig beszámolnak egy magyar szerző olasz nyelvü költeményéröl latinul, amely mint vers, elöször franciául létezik majd.

${ }^{54}$ Szigeti Csaba, Egy lehetséges kis magyar irodalomtörténet, A Csittvári krónika filológiája = Doromb Közköltészeti tanulmányok 5., szerk. Csörsz Rumen István, Bp., Reciti, 2017, 219.

55 Piccolomini 2003, i. m. 159. „Azonban egy magyar férfi, / Nemes ember, akinek Pacorus volt a neve $[\ldots] . "$

${ }^{56}$ Maugin 1556, i. m. 112. „Azonban a Pannóniából való Pacorus, a lovagi rend tagja, nemes ember, aki a császár kíséretében volt, beleszeretett Lucresse-be [...].”

${ }^{57}$ Bideaux 1991, i. m. 176-179. 
de Hongrie qui se nommoit Pacours". ${ }^{58}$ A Piccolominitôl leírtaknak megfelelöen, az itt egyértelmúen magyarországinak mondott férfi virágcsokorba rejtett szerelmes versét azután az egyetemi diákok elkérik Lucretia szolgálólányától:

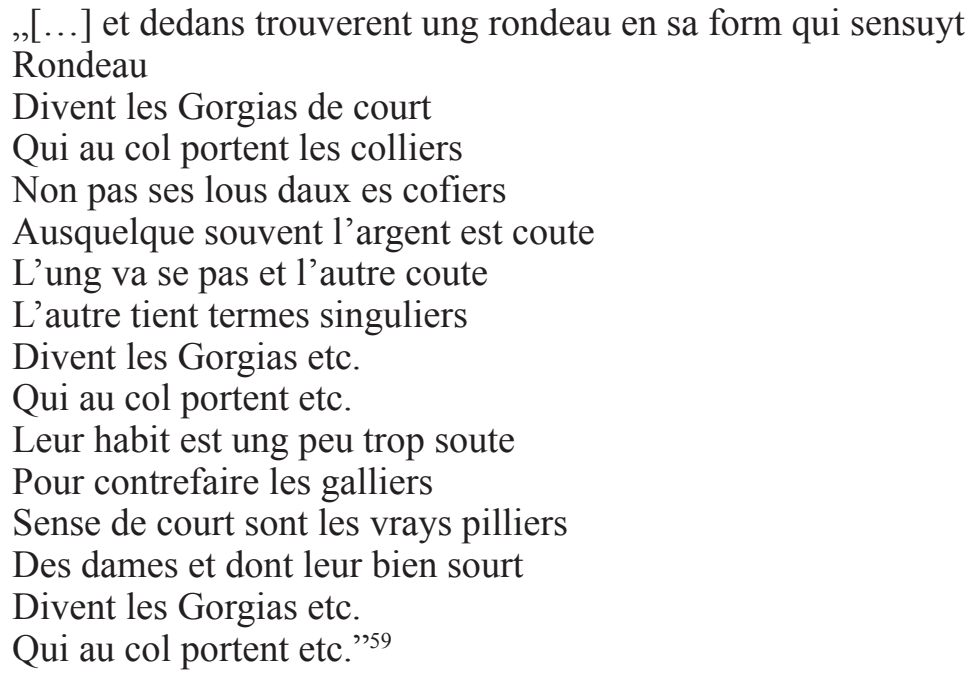

A fent olvasható vers a francia rondó versforma rövidebb altípusába tartozik, rímképlete aabbaabR | abbaR, még ha ezt a magyar fordításban nem is sikerült visszaadni. ${ }^{60} \mathrm{~A}$ francia szöveg megfelel a versforma kívánalmainak, de tartalma egy kissé homályos, az udvari élet szereplőit, a gazdag kincstárnokokat állítja szembe a hölgyek kegyeivel jutalmazott udvaroncokkal. Azt nem sikerült kiderítenem, hogy a költemény eredeti munka-e, vagy már létező szöveg beillesztése a szerelmi históriába, de az előbbit valószínüsítem.

Végül a francia Historia-fordítások utolsó 16. századi képviselője, az ismeretlen N. R. monogramú szerző bővítette ki leginkább a Piccolomininél talált részt Pacorusról. Először is, számára a lovag nem kifejezetten magyar, hanem

${ }^{58}$ FAURE 1508, E1v. „egy nemesi házból való lovag, Magyarországról, akit Pacoursnak hívtak.”

59 FAURE 1508, i. m. E2r. ,és ahogy megkapták, egy rondót találtak benne, mely a következőképp hangzott: Rondó Az udvar Gorgiászaivá azok válnak / Kik nyakukon nyakláncot hordanak / Nem az a két nyomorult kincstárnok / Amikor csak pénzre van szükségük / Az egyik elmegy s a másik bajt okoz / S még másik különös szavakat használ / Az udvar Gorgiászaivá azok válnak / Kik nyakukon nyakláncot hordanak / Ruhájuk kissé túl rövid / Hogy a víg embereket utánozzák / Az udvar elméi ők és igaz támaszai / A hölgyeknek, kiktől vagyonuk is származik / Az udvar Gorgiászaivá azok válnak / Kik nyakukon nyakláncot hordanak” A francia szövegek értelmezésében Benda Mihály (MTA BTK ITI) és Kovács Eszter (SZTE Francia Tanszék) volt segítségemre, amit ezúton is köszönök nekik.

${ }^{60}$ Világirodalmi lexikon, XII. kötet: Rjab-Sez, főszerk. Szerdahelyi István, Bp., Akadémiai Kiadó, 1991, 162. 
szlavóniai úriemberről beszél: „Panfore gentilhomme Sclavon.” ${ }^{11}$ Ha jól értem, a fordító felfogása szerint latin nyelven a népet, illetve a területet a klasszikus fogalmaknak megfelelően kell leírni (pannonius), de a francia nyelvü fordításban már a kortárs állapot szerint ott élő népet veszi figyelembe, s ezért lesz a lovag Szlavóniából származó ember. ${ }^{62}$ A lovag névalakjának Pacorus $\rightarrow *$ Panforus $\rightarrow$ Panfore megváltoztatására azonban csak kulturális okokra visszavezethető magyarázatot tudok adni. A fordító talán etimológiai viccet csinál abból, hogy a termékeny Pannóniát a jó kenyér, panis vidékének tartották. A régi francia nyelv ismerte a painfere fönevet, amely a latin panem ferens 'valaki, aki kenyeret hoz' kifejezéssel áll kapcsolatban. ${ }^{63}$

Hogy mennyi igaz etimológiai fejtegetésemből, nem tudom, annyi azonban bizonyos, hogy a fordító egy úriemberhez méltó mủveltséggel ruházza fel a pannoniust. Panfore nevében a fordító ugyanis elöbb egy verset, majd egy szép levelet is ír Lucretiának, amelyek tehát jelentős betoldások a francia szövegben az eredeti latinhoz képest.

Pacorus virágcsokorba rejtett verse ezúttal egy alexandrinban írott, nyolc versszakos keresztrímes költemény, madrigál:

Mon coeur n'affecte rien que vostre obeissance,

Son souverain bon-heur est sa captivité:

Si ce n'estoit pour vous i'hayrois ma naissance,

Car sans vous l'estre est pis que n'avoir point esté.

Quand ie voy de voistre oeil la lumiere esclattante, Ie tiens pour folle erreur n'avoiier qu'un soleil, Car ou n'y en a point, ou l'oeil qui me tourmente

Est un second Phoebus pius qu'il est tout pareil.

Pour l'autre m'est fort peu, pour le vostre idolastre

I'admire en m'y brusiant son rayon adoré,

Et n'appelle ma terre, ou cruelle, ou marastre,

Que pour m'avoir nourri sans en estre esclairé.

Car sans estre i'estois, ie voyois sans lumiere,

Et mon corps se mouvoit, mais sans vray movement:

I'estois en mesme estat que la prime matiere,

Qui de la form attend son accomplissement.

${ }^{61}$ N. R. 1598 , i. m. 97 r.

${ }^{62} \mathrm{http}: / / \mathrm{www}$. raremaps.com/gallery/enlarge/41504

${ }^{63} \mathrm{http}$ //atilf.atilf.fr/scripts/dmfAAA.exe?LEM=painfere;XMODE=STELLa;FERMER;;AFFICHAGE $=0 ; \mathrm{MENU}=$ menu_dmf;;ISIS=isis_dmf2015.txt;MENU $=$ menu_recherche_dictionnaire; OUVRIR_MENU $=1 ; \mathrm{ONGLET}=\mathrm{dmf} 2015 ; \mathrm{OO} 1=2 ; \mathrm{OO} 2=1 ; \mathrm{OO} 3=-1 ; \mathrm{s}=\mathrm{s} 0 \mathrm{a} 5 \mathrm{a} 23 \mathrm{a} 0 ; \mathrm{LANGUE}=\mathrm{FR}$; 
Ie le receus alors qu'á la premiere veuë

De l'astre de vos yeux, vostre feu m'esclaira,

Et chassant de ses rais l'espassier de la nuë

Qui me cachoit le iour des ombres me tira.

Ce fut lors, beau soleil, que vous fistre descendre

Dans mon sein mille feux, dont unique en beauté

Vous bruslastes mon coeur, Pheonix reduit en cendre

Pour renaistre tousiours unique en loyauté. ${ }^{64}$

A vers arra a középkori felfogásra épül, hogy az emberi szemből kiáradó sugarak vetülnek a tárgyakra, s ettől lát az ember, így a szerelmes férfi is csak attól létezik, ha hölgye rátekint. Innen logikus asszociációval a hölgy a naphoz (soleil) és a napisten Phoebushoz lesz hasonló. Majd a harmadik versszakban a férfi arról panaszkodik, hogy a női nap nem teszi őt párjává, a földdé, bár táplálja anélkül, hogy szándékosan rávetné fényét. A negyedik szakasz arra a képre van felépítve, hogy a hölgy mint éltető erő nélkül a férfi minden cselekedete csak látszat, és igazi tartalommal csak a hölgy által telne meg, mint az első- vagy ősanyag, amely még nem nyert formát, s így minősége sem meghatározható. Az ötödik és hatodik versszakban visszatérnek a nap és a fény metaforái, a záró strófában kiegészülve a férfi mint a hamvaiba haló Főnix képével, aki a hölgy különleges szépsége miatt mindig új életre és az ő szolgálatára támad fel.

Az első szerelmes vers után az N. R. monogramú fordító megíratja szereplöjével a Lucretiának szóló második levelet is, amelyet a hógolyóba rejtve dob be a hölgy ablakán:

Madame Si mon amour eust esté subiet au vent de la fortune, le cruel reuers qu'elle luy a deschargé si tost qu'il a osé paroistre, l'eust tellement affoibly, que sans se pouvoir relever il fust demeuré comme estouffé á sa naissance. Mais estaint composé d'une plus solide trempe, que tout se qui peut changer de face aux atteintes de ceste inconstance Deesse, il veut renaistre sous ses pieds, trop leger pour

${ }^{64}$ N. R. 1598, i. m. 97-100. „Szívem nem vágyik másra, mint hogy Önnek engedelmeskedjék, / S legfőbb boldogsága rabságában áll: / Ha Ön nem volna, születésem is bánnám, / De Ön nélkül létezni rosszabb, mintha soha nem is lettem volna. Amikor látom szemei világosságát, / Örült tévedésnek hiszem, hogy csak egyetlen Napunk van, / De nem így van, mert lelkemet gyötrő szemei / Egy második Phoebushoz hasonlatosak. A másik nap a számomra, az Ön bálványimádójaként, kevéssé erős, / csodálom és imádott sugarai táplálnak, / És földemre csak azt mondom, ó gonosz, ó mostoha, / hogy fénye nélkül táplált engem. Mert lét nélkül léteztem, s fény nélkül láttam, / És a testem mozgott, de igazi mozgás nélkül: / Olyan voltam, mint az ősanyag, / Mely arra vár, hogy formát öltsön és kiteljesedjék. Az első pillantásától nyertem formát / Az Ön szeme csillaga megvilágított, / Sugaraival elüzte a vastag felhőt szemem elől / Mely elrejtette előlem a napot, kivezetett az árnyékból. Akkor történt, szép napom, hogy páratlan szépsége ezernyi lángot gyújtott keblemben / s perzselt szívem, mint a hamuvá vált Főnixmadár, / mely mindig újjáéled, páratlan hüségre." 
luy faire perdre la vie en le foulant, et vous passoistre aussi divin que sa cause est divin. C'est Vous seule, ma Belle, ne le desdaignez donc point, et il desdaignera la puissance d'un contrarie destin, de la mordant envie et de toutes les ialouses rigueurs d'un mary forcené. Si vous le fortifiez de vostre adveu, et de quelque tesmoignage d'un peu de reciproque, mon maleur vaincu faisant ioug á la violence de mes flammes et á la constance de ma fidelité, ne me pourrá empecher d'acquerir le bien oú i'aspire, me disant.

Vostre Serviteur PANFORE ${ }^{65}$

A kacifántos mondatokba szőtt kérés és fogadalom a szerelem alakulását Piccolomini eredeti szövegének szellemében a szerencse, ,az állhatatlan Istennő” szeszélyétől alakított dolognak tartja, amely szeszéllyel csak egy alkalmazkodni képes, erős fából faragott férfi tud ellenállni. Panfore retorikus rábeszélése ellenére Lucretia ebben a történetben sem lesz a magyar lovagé. Piccolomini történetének megfelelően e levél sem jut el az asszonyhoz, hiszen férje, a korábbinál is dühösebb Menelaus kezébe kerül, akinek vádló hangú könyörgésére Zsigmond császár az udvaronca erkölcsi gyengeségén pironkodva küldi el Panfore-t a szolgálatából.

A történet eredeti kimenetele tehát nem változik meg a két francia fordításában sem, csupán a magyarországi irodalom lesz gazdagabb néhány franciául írt költeménnyel és egy levéllel. A fentiekhez hasonló bővítésre a korai Historia-fordítások között máshol nincs is példa, így a Pataki Névtelenként ismert magyar fordító sem bővíti ki saját históriás énekét elképzelt honfitársa soraival. A fent bemutatott szövegek tehát csupán az elképzelt magyar irodalom korpuszát erősíthetik, és adalékként szolgálnak a nyugat-európai irodalmak magyarságképéhez.

${ }^{65}$ N. R. 1598, i. m. 105-107. „Asszonyom, ha szerelmem a szerencse szelének tárgya, a kegyetlen ellenségé, mely lesújt mindenekre, amik ellen mernek állni neki, az oly gyenge, hogy anélkül, hogy felemelkedne, lezuhan, mintha születésétől földre lenne sújtva. De keményebb fából faragták azt, aki meg tudja változtatni arcát, hogy ellenálljon ennek az állhatatlan Istennőnek, és képes újjászületni lábainál, amely túl könnyünek bizonyul ahhoz, hogy eltapossa életét, és az ön csapdája is isteni, hogyha annak okozója isteni. Csakis Ön az, Szépségem, aki egyáltalán nem veti meg az afféle embert, s akkor ő fogja megvetni az ellenkező végzet, a harapós irigység és egy kényszerházasságban magához adott férj minden szigorú féltékenységének hatalmát. Ha ön beleegyezését adja, s érzelmeink kölcsönösségéről egy kis tanúságot tesz, akkor az én szerencsétlenségem, amelyet maga alá hajtott lángjaim erőszakos igája és hüségem kitartása, sem fog megakadályozni benne, hogy elérjem a jót, amelyet annyira óhajtok, esküszöm. Az Ön szolgája, Panfore” 


\section{MÁTÉ, ÁGNES \\ Pacorus et quelques sources francaises de l'ancienne littérature hongroise imaginaire $\left(16^{\mathrm{e}}\right.$ siècle $)$}

Dans mon étude, je traiterai des traductions françaises de la nouvelle Historia de duobus amantibus d'Aeneas Silvius Piccolomini. La première partie de mon étude est de nature bibliographique : il s'agit simplement de corriger quelques erreurs figurant dans le catalogue French Vernacular Books et de fournir des renseignements sur les traductions françaises et leurs auteurs. La seconde partie est consacrée au rôle que remplit dans l'intrigue de la nouvelle le personnage prétendument 'hongrois': j'examine les interprétations que les traducteurs donnent de l'appartenance de Pacorus à la nation pannonius et les transformations qu'ils font subir à sa personne. Il s'avérera que deux des traducteurs français n'ont pas hésité à sacrer poète notre héros: ils lui ont fait 'composer' les deux lettres à Lucretia que Piccolomini a seulement mentionnées. Belle contribution au corpus 'imaginaire' de la littérature hongroise...

Keywords: 16th Century; bibliography; French translations; image of Hungarians; Historia de duobus amantibus. 